\title{
PUSHOVER ANALYSIS OF REINFORCED CONCRETE FRAMES
}

\author{
Mila Svilar ${ }^{1}$ \\ Aleksandar Prokić
}

UDK: 624.072.33:519.6

DOI: 10.14415/konferencijaGFS2019.033

Summary: In this paper the reinforced concrete frame is designed in accordance with modern seismic regulations, whose concept of calculation is based on reduced elastic inertial seismic forces by the reduction factor, while ensuring adequate ductility in all critical regions. Seismic analysis of structures in which the load capacity and ductility is introduced can be performed only if a nonlinear method is applied. This paper presents a conventional static non-linear ("pushover") analysis for estimating the size of seismic forces and nonlinear behavior of the building. The building is modeled in the software package Abaqus with the introduction of geometric non-linearity into the calculation.

Keywords: pushover analysis, nonlinear analysis, modeling of FEM, reinforced concrete frame.

\section{INTRODUCTION}

In seismic analysis, the earthquake effect is displayed through the acceleration of the underlying soil in the form of time acceleration or in the form of an elastic spectrum of the soil acceleration response. Seismic construction response is a very complex process because the behavior of the structure depends on the effects of the earthquake, as the effect of the earthquake on the structure depends on the behavior of the structure.

The rules for the calculation of seismic resistance structures are based on the concept of designing structures to achieve acceptable behavior due to seismic effects. The main goal is to ensure that objects resist small earthquakes without damage, moderate earthquakes with damages of non-structural elements, and for strong earthquakes to prevent the demolition of objects exposed to seismic activity. Severe earthquakes occur very rarely and therefore it is not economical to design and execute a structure that would remain in the elastic area for this type of load or with moderate damage. [1].

Aseismic design of reinforced concrete buildings is based on the controlled tolerance of the occurrence of damage in certain supporting elements ("programmed behavioral method") in the case of moderate and severe earthquakes, without demolition of structures, and in order to dissipate seismic energy. A simplified way to introduce nonlinear effects into calculation is an analysis of a linearly-elastic model with reduced

\footnotetext{
${ }^{1}$ Mila Svilar, dipl.inž.građ., University of Novi Sad, Faculty of Civil Engineering Subotica, Kozaračka 2a, Subotica, Serbia, tel: ++381 24554 300, e-mail: svilarm@gf.uns.ac.rs

${ }^{2}$ Prof. dr Aleksandar Prokić, dipl.inž.građ., University of Novi Sad, Faculty of Civil Engineering Subotica, Kozaračka 2a, Subotica, Serbia, tel: ++381 24554 300, e-mail: aprokic@eunet.rs
} 
Савремена достигнућа у грађевинарству 23-24. април 2019. Суботица, СРБИЈА

seismic forces. This analysis can well evaluate the forces, but not the displacements and deformation quantities. [2]

Reinforced concrete is, by its mechanical properties, a material that can provide a favorable behavior of structures exposed to seismic forces. If properly designed and well executed, reinforced concret construction can develop the required ductility and provide protection against local or global demolition. Skeletal constructions are the most frequently applied constructions in the building industry. They are characterized by relatively high flexibility due to the development of relatively small seismic forces. Due to great flexibility, large shifts occur which can result in significant damage [2].

Nonlinear static analysis is a simplified method for estimating a seismic response that, in addition to its simplicity in application (in comparison with the nonlinear dynamic method), also provides an effective global response to the construction. [3]

In EN 1998-1, the concept of seismic-resistant design is based on controlled load reduction, through force reduction, which is achieved by applying a behavior factor which practically reduces the values of the elastic response spectrum. The required load capacity is determined for the project level of seismic impact, which is several times lower than the values that would occur in the elastic response. This allows a non-linear response for a real seismic effect, with the construction during the earthquake exposed to seismic forces that are approximately equal to its nominal load [4].

\section{NUMERICAL EXAMPLE}

The calculation of the sixth floor reinforced concrete frame was implemented in accordance with the provisions given in EN 1998 for the DCH ductility class. The facility fulfills the conditions of regulation in the basis and in height, so the calculation can be carried out with neglecting the foundation deformability of the underground. The considered fifth floor reinforced concrete frame is of constant floor height $h=3.0 \mathrm{~m}$, with three field ranges (Figure 1). The dimensions of the cross-sections of the pillars are $60 / 60 \mathrm{~cm}$, and the beam is taken as the effective width of the panel, dimensions $140 / 18 \mathrm{~cm}$.

The analysis examined the effects of seismic activity and gravitational (constant and variable) load. The weight of the columns and boards of one floor is 57.19 tonnes, while the total mass of the frame is 285.97 tonnes.

Seismic influences are determined by multimodal analysis with the project spectrum for horizontal direction. In EN 1998-1, an elastic response spectrum for horizontal seismic action is prescribed with the following parameters: the basic oscillation period $\mathrm{T}_{1}=0.669 \mathrm{~s}$, type 1 elastic response spectrum, $\mathrm{C}$ category of soil $\left(\mathrm{S}=1.15, \mathrm{~T}_{\mathrm{b}}=0.2 \mathrm{~s}\right.$, $\mathrm{T}_{\mathrm{c}}=0.6 \mathrm{~s}, \mathrm{~T}_{\mathrm{d}}=2.0 \mathrm{~s}$ ), maximum soil acceleration $\mathrm{a}_{\mathrm{g}}=0.25 \mathrm{~g}$, so the conditions for applying the lateral force method is fulfilled. In determining the seismic force, the behavior factor was obtained:

$$
\begin{aligned}
& q=q_{0} \cdot k_{w g}=4,5 \cdot 1,3 \cdot 1=5,85 \\
& q_{0}=\frac{\aleph_{u}}{\alpha_{1}}, 4,5 \\
& \frac{\Xi_{u}}{\alpha_{1}}=1,3,
\end{aligned}
$$




\section{$7^{\text {th }}$ internATIONAL CONFERENCE}

Contemporary achievements in civil engineering 23-24. April 2019. Subotica, SERBIA

from which it follows that the project spectrum of the response:

$S_{d}\left(T_{1}\right)=a_{g} \cdot S \cdot \frac{2,5}{q} \cdot\left[\frac{T_{c}}{T_{1}}\right]=0,25 \cdot g \cdot 1,15 \cdot \frac{2,25}{5,85} \cdot\left(\frac{0,6}{0,669}\right)=0,0992 g$,

and with the correction factor, the distribution of the force:

$S_{d}\left(T_{1}\right) \cdot W_{U K} \times \lambda=0,0992 g \times 285,97 \times 0,85=236,55 \mathrm{kN}$

The distribution of force per floor is given in Figure 1. Dimensioning of the structural elements was carried out on the basis of the relevant combination (Figure 2). For the dimensioning of the supporting elements, the concrete C25 / 30 and the S 400 were used, and the quantity and arrangement of reinforcement in the beams and pillars were shown in Figure 3.

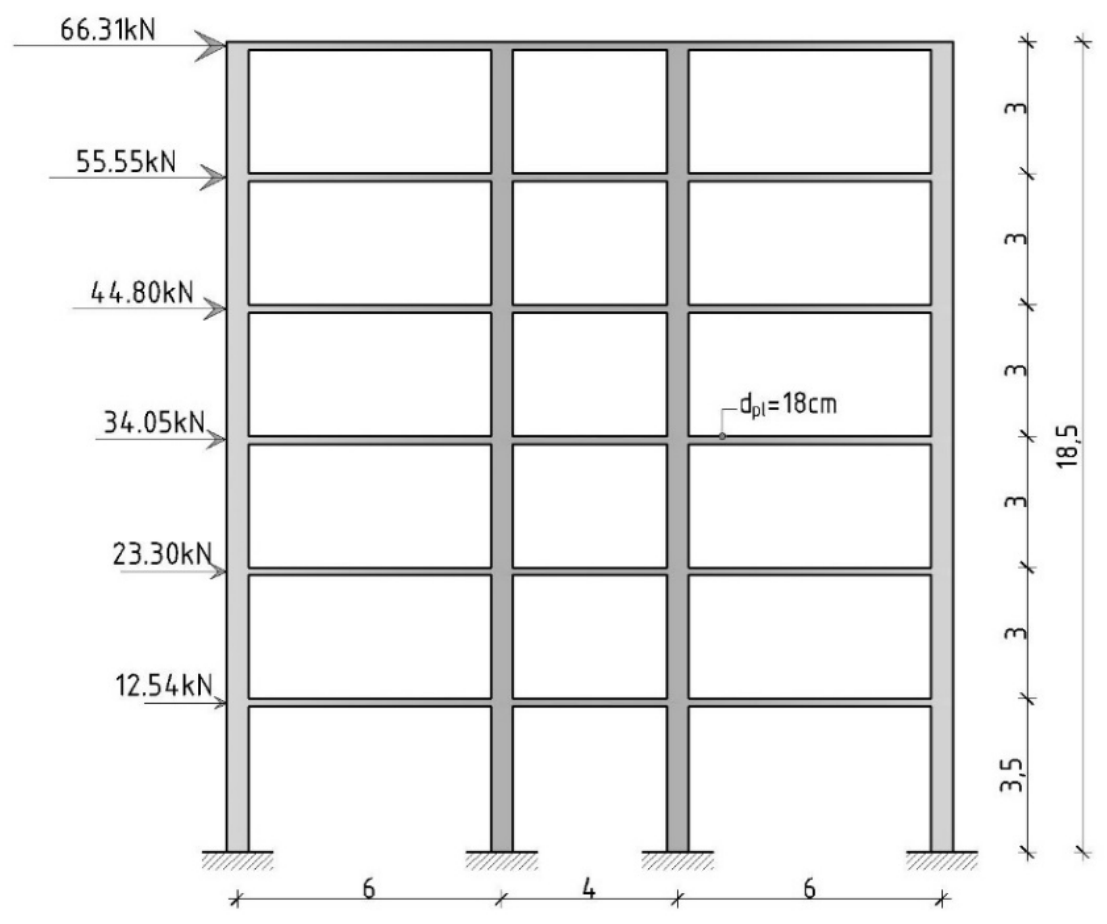

Figure 1 - The distribution of force per floor 
7. МЕЪУНАРОДНА КОНФЕРЕНЦИЈА

Савремена достигнућа у грађевинарству 23-24. април 2019. Суботица, СРБИЈА

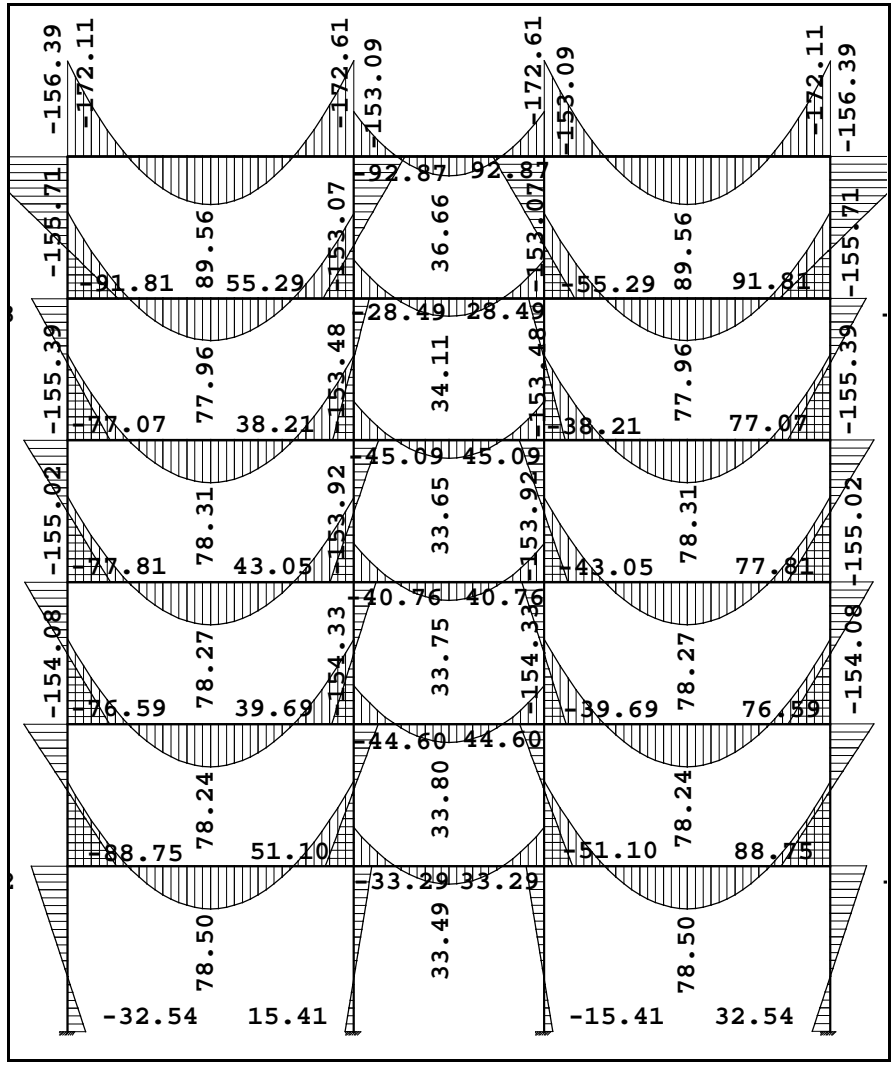

Figure 2 - Bending moment diagram
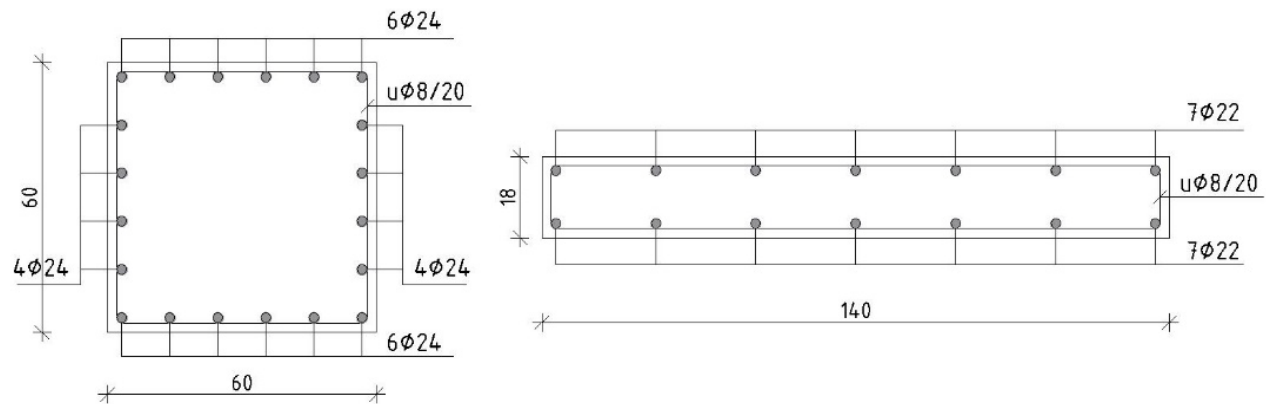

Figure 3 - Adopted reinforcement (left pillar, right beam) 
Contemporary achievements in civil engineering 23-24. April 2019. Subotica, SERBIA

\section{CALCULATION OF THE REINFORCED CONCRETE FRAME IN THE SOFTWARE PACKAGE ABAQUS}

\subsection{Model reinforced concrete structure}

The ABAQUS software package $[5,6]$ was used to simulate the displacement of the reinforced concrete frame and to perform a "pushover" analysis.

ABAQUS 6.7 is a software package based on FEM (Finite Element Methods), which consists of a number of engineering programs. It is developed by Hibbitt, Karlsson \& Sorensen Inc. ABAQUS is one of the comprehensive programs designed to solve a wide range of problems, both related to mechanics, and to other fields of science.

The frame is made up of pillars and beams of given dimensions ( $3 D$ solid deformable part), with all parts rigidly tied. Pillars and beams are reinforced with reinforcement obtained in the previous dimensioning. Pillars are supported by fixed supports (Figure 4).

Since the pillars and beams are modeled as full elements, a C3D8R element is used. It is a cube-shaped element with reduced integration. The element B31 is used for reinforcement, a linear beam with two nodes.

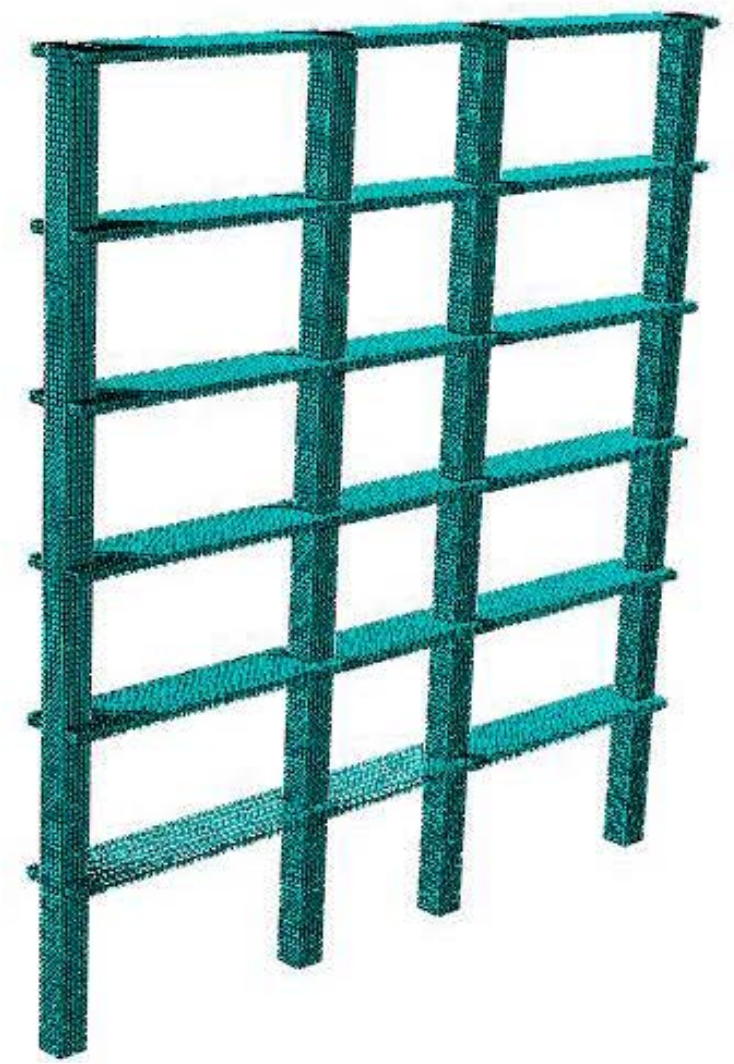

Figure 4 - Finite Element Mesh of the frame 
Савремена достигнућа у грађевинарству 23-24. април 2019. Суботица, СРБИЈА

\subsection{Characteristics of the material}

The material is modeled as elasto-plastic and isotropic for all structural elements. For elastic caracteristics of the concrete the Yang modulus of elasticity is $31476 \mathrm{MPa}$, and Poisson's ratio $v=0.15$. For plastic features

in the model was used "concrete damaged plasticity". The stress-strain relations for compression is given in Figure 5. Bilinear stress-strain relation is used for tensile behaviour and a stress-crack opening relation [7].

For elastic steel characteristics, the Yang modulus of elasticity is $210 \mathrm{GPa}$, and Poisson's ratio $v=0.29$, the Yield strength in the platic characteristics is in the range of 360470MPa.

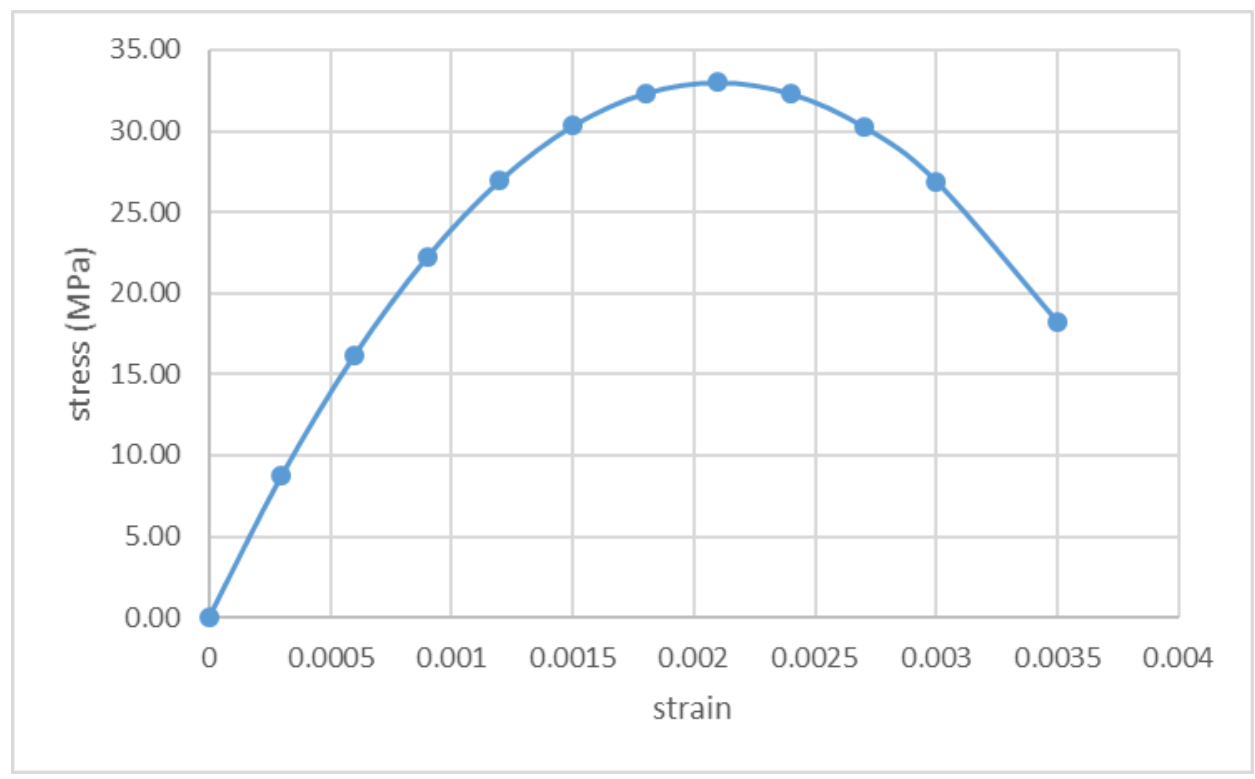

Figure 5 - The stress-strain relations for compression

\subsection{Influences on reinforced concrete frame}

In a nonlinear static, The "pushover" analysis determines the dependency between total shear force and horizontal displacement. Figure 6 shows the horizontal displacement of load forces due to the forces obtained in the calculation.

For the resulting horizontal displacement and total silencing force a "pushover" curve was formed (Figure 7). 
$7^{\text {th }}$

Contemporary achievements in civil engineering 23-24. April 2019. Subotica, SERBIA

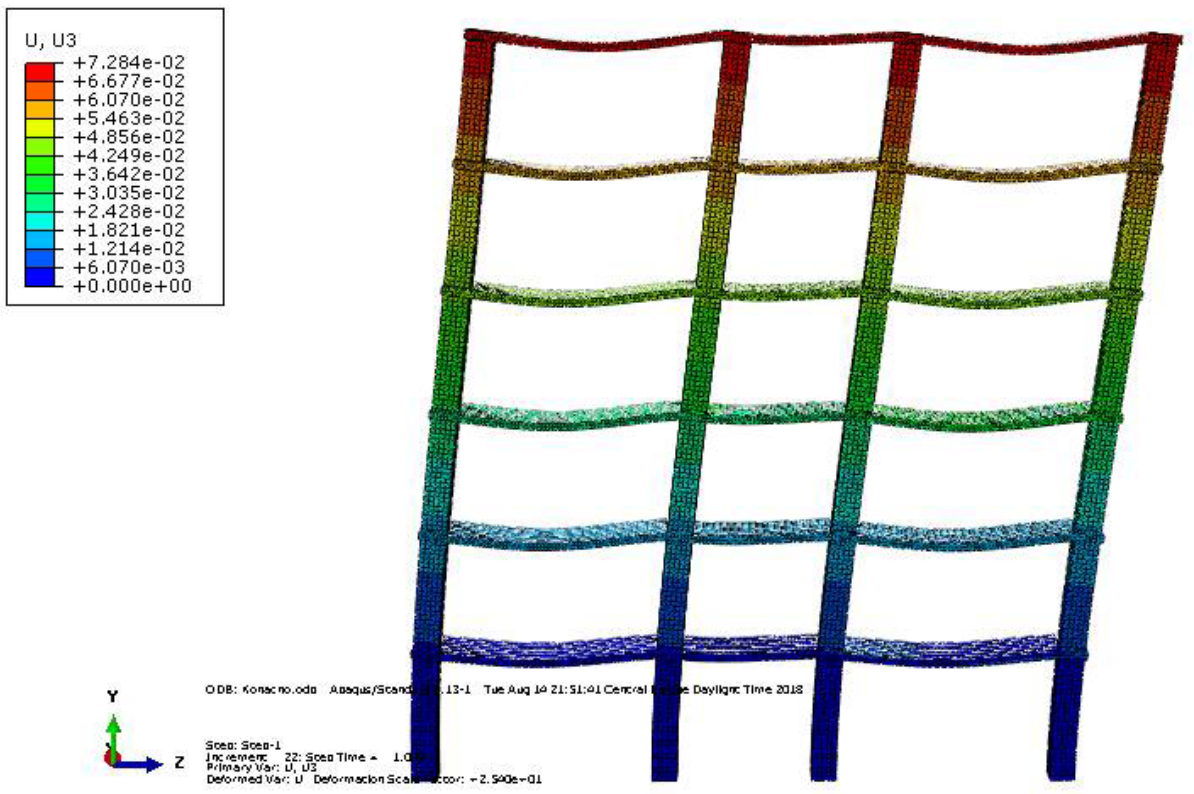

Figure 6 - Horizontal displacement

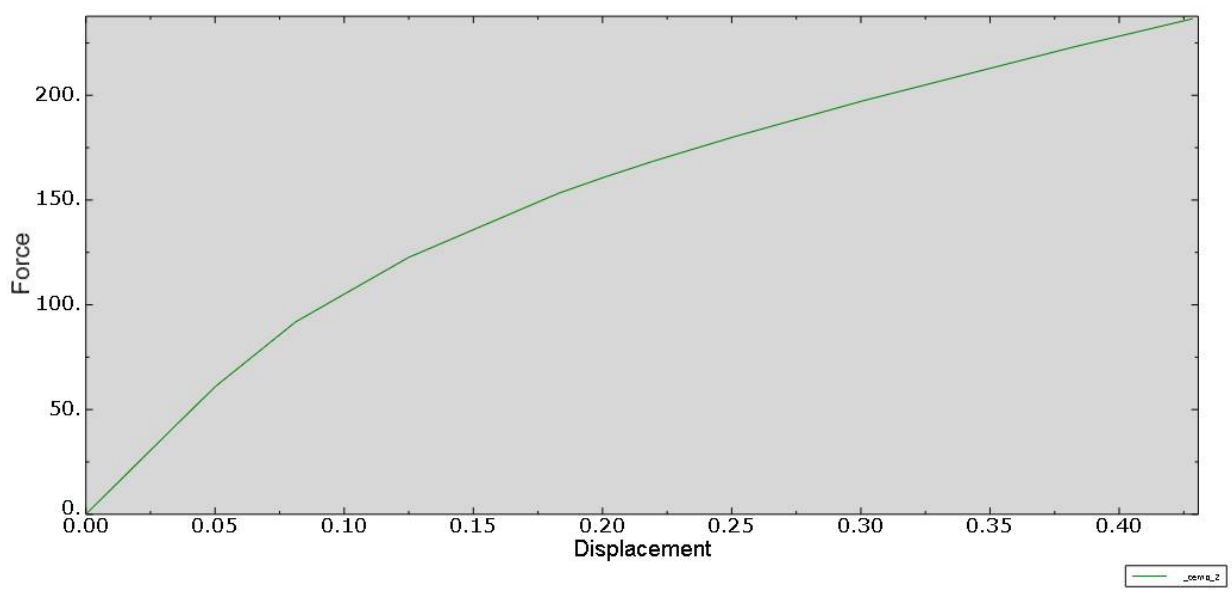

Figure 7 - "Pushover" curve 


\section{CONCLUSION}

On the basis of the obtained results it can be concluded that there was plasticisation in certain cross sections of the beam, but without the formation of a complete fracture mechanism. Nonlinear deformations (and therefore damage) dominantly appeared at the ends of the beam, which is in accordance with the concept of designing reinforced concrete constructions of buildings in seismically active areas. This indicates that the regular reinforced concrete frames, in which the bearing elements are dimensioned in accordance with EN 1998-1, and the seismic effects determined by the application of degraded processes, may develop favorable plastic mechanisms and thereby allow the seismic forces to be absorbed.

\section{REFERENCES}

[1] Radujković A.: Analiza parametara za procenu seizmičkog odgovora višespratnih armiranobetonskih okvira, Doktorska disertacija, Novi Sad, 2015.

[2] Aničić D., Fajfar P., Petrović B., Szavits-Nossan A., Tomažević M.: Zemljotresno inženjerstvo - visokogradnja, Građevinska knjiga, Beograd, 1990.

[3] Radujković A., Rašeta A., Starčev-Ćurčin A., Petronijević M.: Analiza armiranobetonskog okvira visoke duktilnosti, Zbornik radova 20, Građevinski fakultet, 2011.str. 57-68

[4] EN1998-1, Desing of structures for earthquake resistance - Part 1: General rules, seismic actions and rules for buildings, European Committee for Standardization, Brussels, 2004.

[5] Abaqus. Analysis user's manual. version 6.11, Dassault systems, 2007.

[6] Abaqus. Theory manual. version 6.11, Dassault systems, 2007.

[7] fib Model Code for Concrete Structures 2010, Wilhelm Ernst \& Sohn, Verlag für Architektur und technische Wissenschaften GmbH \& Co. KG, Berlin, Germany, p.p. 115-118

\section{„PUSHOVER“ ANALIZA ARMIRANOBETONSKOG OKVIRA}

Rezime: U ovom radu $A B$ okvir je projektovan u skladu sa savremenim seizmičkim propisima, čiji se koncept proračuna zasniva na smanjenu elastičnih inercijalnih seizmičkih sila faktorom redukcije uz obezbeđenje adekvatne duktilnosti u svim kritičnim regionima. Seizmička analiza konstrukcija u kojoj se uvodi u proračun kapacitet nosivosti i duktilnost, može se izvršiti samo ukoliko se primeni nelinearna metoda. $U$ ovom radu je prikazana konvencionalna statička nelinearna ("pushover") analiza za procenu veličine seizmičkih sila i nelinearnog ponašanja zgrade. Zgrada je modelirana u programskom paketu “Abaqus” uz uvođenje geometrijske nelinearnosti u proračun.

Ključne reči: "pushover" analiza, nelinearna analiza, modeliranje MKE, armiranobetonski okvir. 